\title{
Total lipid extracts from characteristic soil horizons in a podzol profile
}

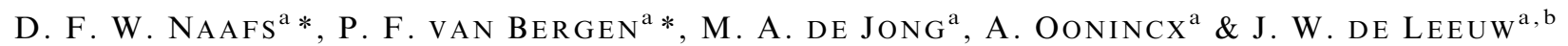 \\ ${ }^{\mathrm{a}}$ Geochemistry, Faculty of Earth Sciences, Utrecht University, PO Box 80021, 3508 TA Utrecht, and ${ }^{\mathrm{b}}$ Royal Netherlands Institute for \\ Sea Research (NIOZ), PO Box 59, 1790 AB Den Burg, Texel, The Netherlands
}

\begin{abstract}
Summary
The podzolization process is studied through lipids in nine characteristic podzol horizons. Organic matter accumulates particularly with aluminium in the Bh horizon, while the hard, cemented Bs horizon below this is formed mainly by iron oxides. The low soil $\mathrm{pH}$ seems to have no great influence on the preservation of lipids as reflected by the absolute amounts present and the presence of bacterial lipid markers throughout the profile. Independent of soil $\mathrm{pH}$, lipids accumulate in organically enriched horizons. Albeit, high molecular weight organic compounds accumulate to a relatively greater extent than lipids in these horizons. A lipid signal related to the aerial parts, i.e. leaves and flowers, of Calluna is observed only in the O horizon. This ' $n$-alkane, steroid and triterpenoids' signal is quickly lost in the underlying Ah horizon due to (bacterial) oxidation. The other total lipid extracts obtained are dominated by root-derived compounds. In subsoil horizons rich in organic matter, i.e. the $\mathrm{Ahb}$ and $\mathrm{Bh}$ horizons, root-derived friedooleanan and steroid compounds dominate the total lipid signal. Degraded horizons, poor in organic matter, i.e. the E2, Bhs, $\mathrm{Bs}$ and $\mathrm{B} / \mathrm{C}$ horizons, are dominated by $\mathrm{C}_{22}$ and $\mathrm{C}_{24} \omega$-hydroxy acids, long-chain $\left(>\mathrm{C}_{20}\right) n$-alkanoic acids with a strong even-over-odd predominance and $\mathrm{C}_{22}$ and $\mathrm{C}_{24} n$-alkanols. Steroid and root-derived triterpenoids with a friedooleanan structure have been removed from these horizons through degradation. Based on total organic carbon content and lipid composition, the formation of an E1 horizon has started, but is not yet complete. In the Ahb horizon, a contribution from buried vegetation to the total lipid signal is still present, although degradation and an input from roots have significantly altered the original signal. Overall, lipid data indicate that degradation (microbial oxidation) is an important process that should be taken into account, in addition to leaching, when describing podzolization processes in soils.
\end{abstract}

\section{Introduction}

Soil lipids are, by definition, organic compounds insoluble in water, but soluble in common organic solvents. They include $n$-alkanoic acids, $n$-alkanols, hydroxy acids, ketones, steroids, terpenoids, acyl glycerols and hydrocarbons, as well as phospholipids and lipopolysaccharides (Stevenson, 1982). These compounds originate from both plants and animals as products of deposition, decomposition and exudation, as well as from various other pedogenic sources, including fungi, bacteria and mesofauna (Bull et al., 2000a). Lipids accumulate in acid soils such as podzols (Jambu et al., 1985). In these, as well as in other soils, their composition is influenced by a wide range of processes, including bioturbation, oxidation, micro-

Correspondence: D. F. W. Naafs. E-mail: Dennis.Naafs@shell.com *Present address: Flow Assurance, Shell Global Solutions International, PO Box 38000, 1030 BN Amsterdam, The Netherlands. Received 3 June 2003; revised version accepted 6 January 2004 bial degradation and hydrolysis. The rate of these processes is directly affected by soil $\mathrm{pH}$, moisture, microbial biomass, etc. (van Bergen etal., 1997, 1998). So far, lipid research in podzols has focused on specific lipid fractions, e.g. $n$-alkanes, $n$-alkanols and $n$-alkanoic acids, mainly in litter and A horizons (e.g. Jambu et al., 1993; Amblès et al., 1998). To our knowledge, no studies on the composition of total lipid extracts throughout the whole podzol profile have been undertaken.

In this paper, the composition of total lipid extracts from nine characteristic podzol horizons from the Veluwe area (a natural park, in the centre of The Netherlands) was determined by gas chromatography (GC) and gas chromatographymass spectrometry (GC/MS). In addition, soil $\mathrm{pH}\left(\mathrm{H}_{2} \mathrm{O}\right)$, and ammonium oxalate- and sodium pyrophosphateextractable aluminium and iron were determined. Results are discussed in terms of the origin of the compounds identified and the processes that effect their distribution in the podzol profile. 


\section{Materials and methods}

\section{Site description}

Samples were taken from a Haplic Podzol (FAO, 1998) at the Veluwe area near Kootwijk/Assel, The Netherlands, which has formed in wind blown sands, deposited during the Pleistocene. Vegetation is dominated by heather (Calluna vulgaris) and moss together with small birch trees. The profile is characterized by a litter layer $(\mathrm{O})$ underlain by several horizons typical of podzols (Figure 1). Recognizable roots and root fragments were found only to a depth of about $52 \mathrm{~cm}$ (start of the Bs horizon).

\section{Sampling, sample pretreatment and inorganic analyses}

Samples were taken in early September 1999 from each horizon and from in between the $\mathrm{Bh}$ and $\mathrm{Bs}$ horizons (referred to as the Bhs horizon in this paper). Samples were dried at $60^{\circ} \mathrm{C}$ and sieved over a $2-\mathrm{mm}$ and a $250-\mu \mathrm{m}$ sieve to remove roots. Soil $\mathrm{pH}\left(\mathrm{H}_{2} \mathrm{O}\right)$ of the soil was measured in the supernatant of a suspension $(1: 2.5$ sieved $(<250 \mu \mathrm{m})$ sample:water $)$ with a Scott Geräte $\mathrm{pH}$ meter CG 805. Sodium pyrophosphate-extractable $\mathrm{Fe}$ and $\mathrm{Al}$ were determined by shaking $0.5 \mathrm{~g}$ of sieved $(<250 \mu \mathrm{m})$ soil overnight (16hours) with $50 \mathrm{ml}$ of $0.1 \mathrm{M} \mathrm{Na}$ pyrophosphate solution. Oxalate-extractable $\mathrm{Fe}, \mathrm{Al}$ and $\mathrm{Si}$

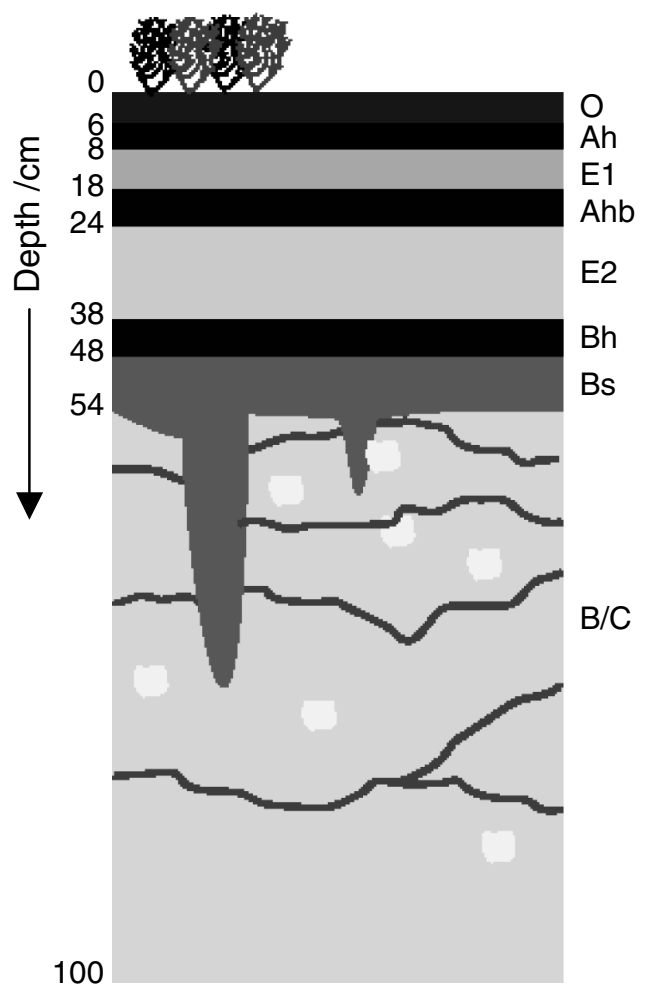

Figure 1 Schematic representation of the podzol profile sampled. Characteristic horizon symbols are indicated at the right. were determined by shaking ( 4 hours in the dark) $0.5 \mathrm{~g}$ of sieved $(<250 \mu \mathrm{m})$ soil with $25 \mathrm{ml} 0.2 \mathrm{M}$ ammonium oxalate solution. Concentrations of $\mathrm{Al}, \mathrm{Fe}$ and $\mathrm{Si}$ were measured with a Perkin Elmer Optima3000 ICP-OES.

\section{Organic analyses}

Total organic carbon contents of sieved $(<250 \mu \mathrm{m})$ soil were measured with a Fisons Instruments NA 1500 NCS analyser, with a cycle time of $180 \mathrm{~s}$, a source temperature of $190^{\circ} \mathrm{C}$ and an oxygen flow of $c .30$ litres minute ${ }^{-1}$. Approximately $15-25 \mathrm{~g}$ of each sieved $(<250 \mu \mathrm{m})$ sample was extracted on a Soxhlet apparatus with dichloromethane/methanol (DCM/MeOH) (9:1 by volume) for 24 hours. The DCM/MeOH extract collected was taken to complete dryness in a rotary evaporator. The dry residue obtained was dissolved in approximately $2 \mathrm{ml}$ $\mathrm{DCM} /$ isopropanol (2:1 by volume), filtered in a Pasteur pipette packed with defatted wool, $0.5 \mathrm{~cm} \mathrm{Na} \mathrm{SO}_{4}$ and $2 \mathrm{~cm} \mathrm{SiO}$, and dried in a stream of $\mathrm{N}_{2}$. Free hydroxyl and carboxylic acid groups present in an aliquot were derivatized to their corresponding trimethylsilyl (TMS) ethers and esters, respectively, by heating for 1 hour at $70^{\circ} \mathrm{C}$ with $\mathrm{N}, \mathrm{O}$-bis(trimethylsilyl)trifluoroacetamide (BSTFA) containing 1\% trimethylchlorosilane. The derivatized aliquots were dried under $\mathrm{N}_{2}$ and dissolved in hexane. An aliquot of a standard solution containing $0.18 \mu \mathrm{g} \mu \mathrm{l}^{-1} 10$-nonadecanone was added. The remaining part of the extract was evaporated to dryness in air.

\section{Gas chromatography (GC)}

Derivatized total lipid extracts in hexane $(1 \mu \mathrm{l})$ were analysed by GC on a Hewlett-Packard 6890 instrument equipped with a CP-sil 5CB silica column $(50 \mathrm{~m} \times 0.32 \mathrm{~mm}$, film thickness $0.12 \mu \mathrm{m})$. Extracts were injected into the column. The oven temperature was programmed from $70^{\circ} \mathrm{C}$ to $130^{\circ} \mathrm{C}$ at $20^{\circ} \mathrm{C}$ minute ${ }^{-1}$, and from $130^{\circ} \mathrm{C}$ to $320^{\circ} \mathrm{C}$ (isothermal for 20 minutes at $320^{\circ} \mathrm{C}$ ) at $4^{\circ} \mathrm{C}$ minute ${ }^{-1}$. Compounds were detected with a flame ionization detector (FID) at $325^{\circ} \mathrm{C}$. Helium was used as carrier gas.

\section{Gas chromatography-mass spectrometry (GC/MS)}

GC/MS analyses were performed on a Hewlett-Packard 5890 series II gas chromatograph connected to a Fisons Instruments VG platform II mass spectrometer operating at $70 \mathrm{eV}$, scanning the range $m / z \quad 50-650$ in a cycle of $0.65 \mathrm{~s}$. The capillary column and temperature programme were as described for the GC analyses. The compounds were identified from their mass spectral data and a NIST library or by interpretation of the spectra and the GC retention times. In addition, compound identification was based on published data (e.g. Holloway, 1982; Killops \& Frewin, 1994; van Bergen et al., 1997). 


\section{Results}

\section{Inorganic soil analyses}

Values for $\mathrm{pH}\left(\mathrm{H}_{2} \mathrm{O}\right)$ ranged from 4.6 to 3.5 (Table 1). From the $\mathrm{O}$ horizon (4.6) to the Ah horizon (3.7), the $\mathrm{pH}\left(\mathrm{H}_{2} \mathrm{O}\right)$ decreased, only to increase again to 4.6 in the E2 horizon. There was most active iron $\left(\mathrm{Fe}_{\mathrm{ox}}\right)$ in the Bs horizon and least in the E2 horizon. The amount of organically complexed $\mathrm{Al}$ $\left(\mathrm{Al}_{\mathrm{py}}\right)$ was greatest in the $\mathrm{Bh}$ horizon and, like the organically complexed Fe, was least in the E2 horizon.

\section{Total organic carbon and quantification of total lipid extracts}

The largest total $\mathrm{C}$ contents $(>5 \%)$ were found in the $\mathrm{O}, \mathrm{Ah}$, $\mathrm{Ahb}$ and $\mathrm{Bh}$ horizons, while both $\mathrm{E}$ horizons together, with the $\mathrm{Bs}$ and $\mathrm{B} / \mathrm{C}$ horizons, contained less than $2 \%$ (Table 2). The $\mathrm{C}$ contents of residues after solvent extraction showed a similar trend to those of the unextracted samples. The yields of total lipid extracts ( $\mathrm{mg} \mathrm{g}^{-1}$ soil) ranged from 0.02 to 2.8 , the highest amounts again being found in the humic horizons. The Ah horizon made the largest contribution of lipids to the total $\mathrm{C}$ on a mass basis.

The composition of total lipid extracts from all nine characteristic horizons

The extract obtained from the $\mathrm{O}$ horizon was dominated by a series of long-chain $\left(>\mathrm{C}_{25}\right)$ odd-over-even dominated $n$-alkanes (Figure 2a), the most abundant being $\mathrm{C}_{31}$ and $\mathrm{C}_{33}$. In addition, steroids and triterpenoids (see Table 3 for characteristic mass fragments and IUPAC names) were detected and included taraxerol, camposterol, stigmasterol, $\beta$-sitosterol, $\mathrm{C}_{29}$ ketosteroid, $\alpha$-amyrin, lupeol, friedoolean-3-one, an unidentified triterpenoid and a $\mathrm{C}_{30}$ triterpenyl acid. Other compounds, present in smaller concentrations, were even-over-odd dominated $\mathrm{C}_{18}-\mathrm{C}_{26} n$-alkanols, $n$-alkanoic acids, ranging from $\mathrm{C}_{14}$ to $\mathrm{C}_{26}, \mathrm{C}_{15}$ iso and anteiso acids, $\mathrm{C}_{18}$ isoprenoid methylketone and short-chain $\left(<\mathrm{C}_{25}\right) n$-alkanes without an oddover-even predominance.

$\mathrm{C}_{31}$ and $\mathrm{C}_{33} n$-alkanes, together with their co-eluting $\mathrm{C}_{29}$ and $\mathrm{C}_{31}$ methylketones, were also fairly abundant in the

Table 1 Inorganic soil analyses

\begin{tabular}{llllllllll}
\hline Horizon: & $\mathrm{O}$ & $\mathrm{Ah}$ & $\mathrm{E} 1$ & $\mathrm{Ahb}$ & $\mathrm{E} 2$ & $\mathrm{Bh}$ & $\mathrm{Bhs}$ & $\mathrm{Bs}$ & $\mathrm{B} / \mathrm{C}$ \\
\hline $\mathrm{pH}\left(\mathrm{H}_{2} \mathrm{O}\right)$ & 4.6 & 3.7 & 3.9 & 3.8 & 4.6 & 3.5 & 3.5 & 4.0 & 4.1 \\
$\mathrm{Al}_{\mathrm{ox}}^{\mathrm{a}} / \%$ & 0.11 & 0.31 & 0.02 & 0.23 & 0.02 & 1.81 & 0.33 & 0.84 & 0.41 \\
$\mathrm{Al}_{\mathrm{py}} \mathrm{b} / \%$ & 0.12 & 0.14 & 0.04 & 0.10 & 0.02 & 0.82 & 0.28 & 0.39 & 0.15 \\
$\mathrm{Fe}_{\mathrm{ox}} / \%$ & 0.07 & 0.23 & 0.02 & 0.18 & 0.01 & 0.87 & 0.61 & 1.54 & 0.07 \\
$\mathrm{Fe}_{\mathrm{py}} / \%$ & 0.07 & 0.17 & 0.03 & 0.07 & 0.02 & 0.42 & 0.52 & 0.75 & 0.03
\end{tabular}

${ }^{\mathrm{a} O x a l a t e}$ extractable.

${ }^{\mathrm{b}}$ Pyrophosphate extractable.
Table 2 Analyses of total organic carbon (TOC) and total lipid extracts (TLEs)

\begin{tabular}{lrrrrrrrrrr}
\hline Horizon: & O & Ah & E1 & Ahb & E2 & Bh & Bhs & Bs & B/C \\
\hline TOC /wt \% & 10.1 & 7.8 & 2.0 & 5.3 & 0.6 & 6.6 & 1.7 & 1.2 & 0.4 \\
TOC Sox. Res. & a $/$ wt $\%$ & 9.6 & 7.3 & 1.6 & 4.9 & 0.5 & 5.7 & 1.2 & 1.1 & 0.4 \\
TLEs $/ \mathrm{mg} \mathrm{g}^{-1}$ soil & 2.2 & 2.8 & 0.3 & 1.1 & 0.1 & 1.6 & 0.2 & 0.1 & 0.1 \\
TLEs $/ \mathrm{mg} \mathrm{g}^{-1}$ TOC & 21.9 & 35.7 & 13.0 & 20.8 & 22.3 & 24.2 & 12.9 & 3.9 & 6.7 \\
\hline
\end{tabular}

${ }^{\text {a }}$ Soxhlet residue.

extract of the $\mathrm{Ah}$ horizon (Figure 2b). In addition, a $\mathrm{C}_{29}$ ketosteroid together with triterpenoids including taraxerone, friedoolean-3-one and an unknown steroid, dominated the last part of the chromatogram. Even-over-odd dominated $\mathrm{C}_{12}-\mathrm{C}_{32}$ $n$-alkanoic acids and $\mathrm{C}_{23}-\mathrm{C}_{28}$ odd-over-even dominated methylketones were found in relatively large concentrations. Apart from saturated linear fatty acids, $\mathrm{C}_{15}$ iso and anteiso acids and one $\mathrm{C}_{18} n$-alkenoic acid were found. $\beta$-sitosterol was present only in smaller concentrations, together with even $\mathrm{C}_{20}$ $\mathrm{C}_{26}$ n-alkanols, the $\mathrm{C}_{18}$ isoprenoid methylketone, $\mathrm{C}_{22}$ and $\mathrm{C}_{24}$ $\omega$-hydroxy acids, and short-chain $\left(<\mathrm{C}_{25}\right) n$-alkanes without an odd-over-even predominance.

The only difference between the extract obtained from the E1 horizon (Figure 2c) and that from the Ah horizon (Figure $2 b)$ was the further increase in relative concentration of the $n$-alkanoic acids. In contrast, $n$-alkanoic acids were much less important in the Ahb extract (Figure 2d), which extract was characterized both by $\beta$-sitosterol and by the $\mathrm{C}_{29}$ ketosteroid. Other important compounds were friedoolean-2-ene, T2, friedoolean-3-one, T9, stigmasterol (Table 3), $\mathrm{C}_{22}$ and $\mathrm{C}_{24}$ $n$-alkanols, and the co-eluting $\mathrm{C}_{31} n$-alkane and $\mathrm{C}_{29}$ methylketone.

In the E2 horizon, the relative contribution of steroids and triterpenoids was smaller again, whereas the even-over-odd dominated $n$-alkanoic acids, $n$-alkanols and $\mathrm{C}_{22}$ and $\mathrm{C}_{24}$ $\omega$-hydroxy acids were more abundant (Figure 2e). Two short-chain, i.e. $\mathrm{C}_{8}$ and $\mathrm{C}_{9}, \omega$-hydroxy acids were identified together with phytol, $\mathrm{C}_{23}-\mathrm{C}_{31}$ methylketones and $\mathrm{C}_{12}$ and $\mathrm{C}_{14}$ $n$-alkanoic acids.

The compound $\beta$-sitosterol and a $\mathrm{C}_{29}$ ketosteroid, together with several triterpenoids including friedoolean-2-ene, taraxerone, taraxerol and friedoolean-3-one, characterized the extract obtained from the Bh horizon (Figure 2f), similar to the Ahb horizon extract (Figure 2d). Other fairly abundant compounds included $\mathrm{C}_{22}$ and $\mathrm{C}_{24} n$-alkanols and $n$-alkanoic acids. In addition to a series of odd-over-even dominated ketones $\left(\mathrm{C}_{23}-\mathrm{C}_{31}\right), n$-alkanes without a clear odd-over-even dominance $\left(\mathrm{C}_{20}-\mathrm{C}_{23}\right)$ were identified.

The $\mathrm{C}_{22}$ and $\mathrm{C}_{24} \omega$-hydroxy acids were found to dominate the extract obtained from the Bhs horizon in addition to an even-over-odd dominated series of $n$-alkanoic acids $\left(\mathrm{C}_{10}-\mathrm{C}_{28}\right)$ and $n$-alkanols $\left(\mathrm{C}_{14}-\mathrm{C}_{28} ;\right.$ Figure $\left.2 \mathrm{~g}\right)$. Compounds present in 


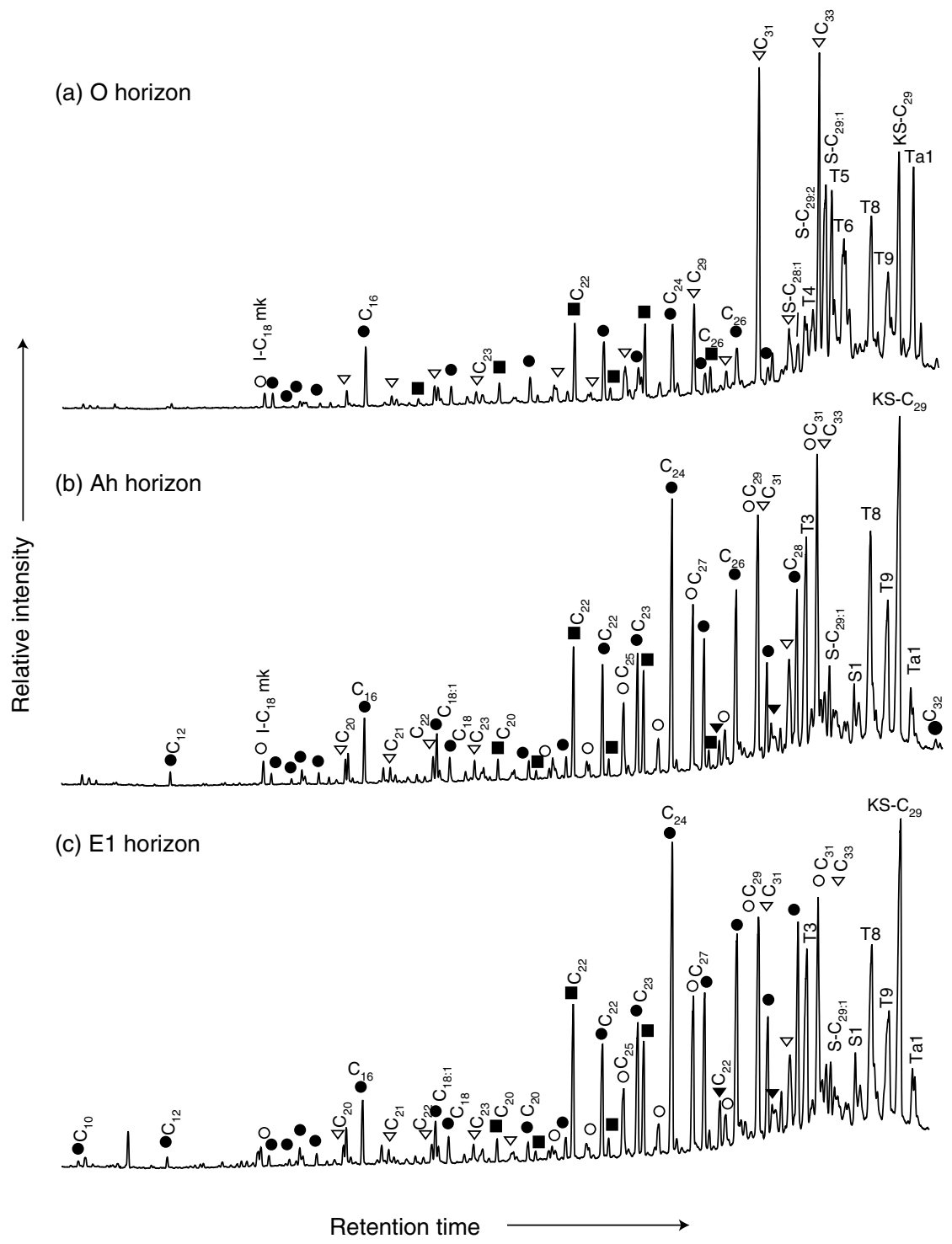

Figure 2a-c

smaller concentrations included $n$-alkanes $\left(\mathrm{C}_{18}-\mathrm{C}_{23}\right), \beta$-sitosterol, taraxerone, friedoolean-3-one, the $\mathrm{C}_{29}$ ketosteroid, as well as ketones $\left(\mathrm{C}_{23}-\mathrm{C}_{29}\right)$ and two saccharides.

The Bs horizon total lipid extract was characterized by a series of even-over-odd dominated $\mathrm{C}_{12}-\mathrm{C}_{28} n$-alkanoic acids maximizing at $\mathrm{C}_{18}, \mathrm{C}_{22}$ and $\mathrm{C}_{24}$ (Figure 2h). In addition, a series of even-over-odd dominated $n$-alkanols ranging from $\mathrm{C}_{14}$ to $\mathrm{C}_{28}$ and maximizing at $\mathrm{C}_{20}, \mathrm{C}_{22}$ and $\mathrm{C}_{24}$, was found. Other compounds detected were $\beta$-sitosterol, $\mathrm{C}_{22}$ and $\mathrm{C}_{24}$ $\omega$-hydroxy acids, $\mathrm{C}_{27}$ and $\mathrm{C}_{29}$ ketones, a saccharide, taraxerone and friedoolean-3-one.

Like the sample obtained from the Bhs horizon (Figure $2 \mathrm{~g})$, long-chain $\left(>\mathrm{C}_{20}\right)$ n-alkanoic acids together with $\mathrm{C}_{22}$ and $\mathrm{C}_{24} \omega$-hydroxy acids characterized the $\mathrm{B} / \mathrm{C}$ horizon extract (Figure 2i). Although there was a small increase in the relative concentration of $\mathrm{C}_{20} n$-alkane and the longchain $n$-alkanoic acids, the $\mathrm{B} / \mathrm{C}$ extract resembled to a great extent the extract obtained from the overlying Bhs horizon (Figure 2h).

\section{Discussion}

Inorganic and bulk organic soil analyses

The largest amounts of aluminium and iron complexed with organic matter, i.e. $\mathrm{Al}_{\mathrm{py}}$ and $\mathrm{Fe}_{\mathrm{py}}$, are found in the $\mathrm{B}$ horizons (Bh, Bs; Table 1). According to these data, soluble organic matter transported down the profile is immobilized in particular by aluminium in the Bh horizon (Lundström et al., 1995; Wesselink et al., 1996). The $\mathrm{Al}_{\text {ox }}$ and $\mathrm{Fe}_{\text {ox }}$ data, in combination 


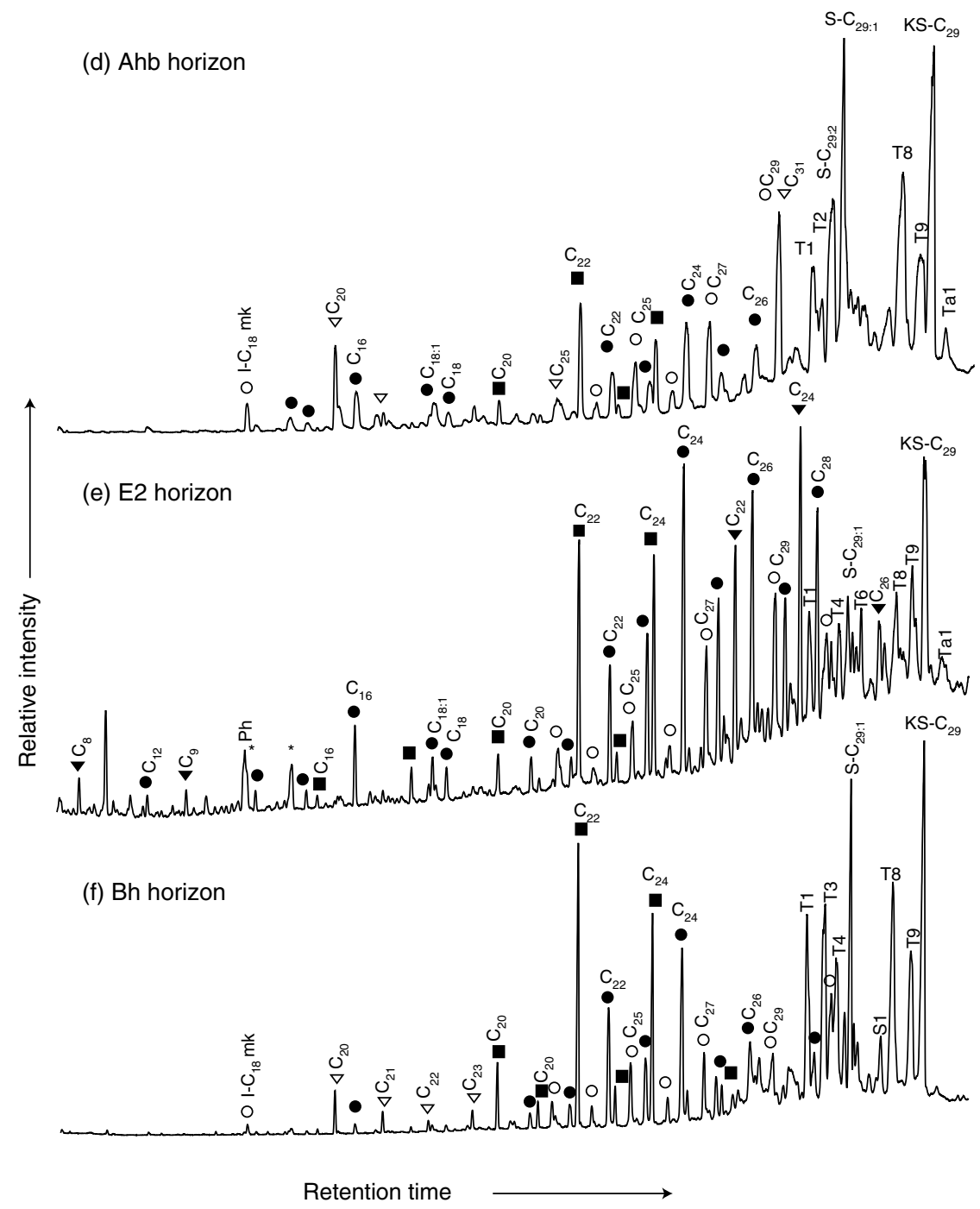

Figure 2d-f

with $\mathrm{Al}_{\text {py }}$ and $\mathrm{Fe}_{\mathrm{py}}$ data, show that the $\mathrm{Bs}$ horizon is mainly formed by Fe oxides (Table 1).

Acid soils are known to enhance the preservation of lipids (Jambu et al., 1985; van Bergen et al., 1998; Bull et al., 2000a). All concentrations of extractable lipids, with the exception of the Ah sample, where it is $35.7 \mathrm{mg} \mathrm{g}^{-1}$ total $\mathrm{C}$ (Table 2), lie within the range of $2-25 \mathrm{mgg}^{-1}$ normally found for soils (Stevenson, 1982). The low soil $\mathrm{pH}$ therefore seems to have no great influence on the preservation of lipids in the soil profile studied.

The change of total $\mathrm{C}$ with depth (Figure 3) clearly indicates the presence of layers (E1 and E2) containing little organic carbon, an accumulation of organic matter (Ah, Bh), and a litter layer $(\mathrm{O})$. The $\mathrm{Bhs}$, Bs and $\mathrm{B} / \mathrm{C}$ samples contain small amounts of organic matter, indicating that its accumulation occurs mainly above the hard, cemented Bs horizon (De Coninck, 1980). In addition to these characteristic horizons (van Breemen \& Buurman, 1998), accumulated organic matter was found in the buried A horizon (Ahb). The newly formed E1 horizon on top of this Ahb horizon (Figure 1) still contains 2\% total $\mathrm{C}$ (Table 1 and Figure 3), suggesting that the formation of this horizon has started, but is not yet complete.

The absolute amounts of extracted lipids (Figure 3) show a strong correlation with the total $\mathrm{C}$ contents (Figure 4 in which $r=0.94)$. When the Ah horizon is excluded, the correlation is even stronger $(r=0.98)$, showing that lipids accumulate in organic-rich horizons. Comparison of the contribution of lipids to the total $\mathrm{C}$ with the $\mathrm{C}$ content itself reveals that lipids do not accumulate relative to other forms of soil organic matter in these horizons. In other words, organic compounds other than lipids have accumulated even more than lipids in podzol B horizons (Schmidt et al., 2000). The relatively large contribution of lipids to the total amount of organic carbon in the E2 horizon (Table 2) could arise because hydrophobic 


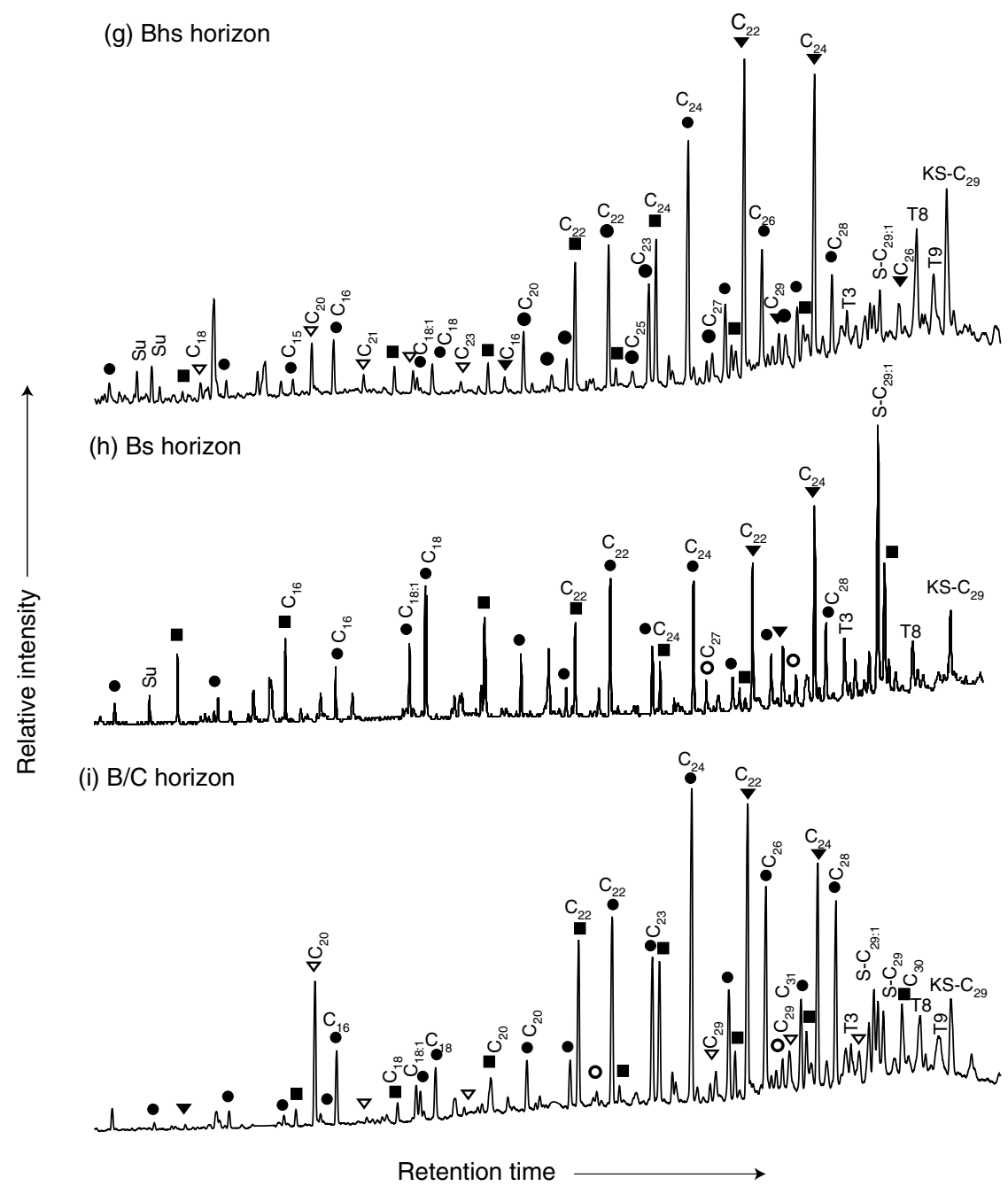

Figure 2 Gas chromatograms of total lipid extracts (TLEs) obtained from: (a) O horizon, (b) Ah horizon, (c) E1 horizon, (d) Ahb horizon, (e) E2 horizon, (f) Bh horizon, (g) Bhs horizon, (h) Bs horizon, and (i) B/C horizon. Key: $\mathbf{m}, n$-alkanols; $\bullet, n$-alkanoic acids; $\nabla, n$-alkanes; $\boldsymbol{\nabla}, \omega$-hydroxy acids; O, ketones; $\mathrm{Su}$, saccharide; $\mathrm{I}_{-} \mathrm{C}_{18} \mathrm{mk}$, isoprenoid methylketone; $\mathrm{Ph}$, phthalate. $\mathrm{C}_{x}$ refers to the total number of carbon atoms. $\mathrm{S}-\mathrm{C}_{x}$ refers to steroids with $x$ being the total number of carbon atoms. KS-C $x$ refers to ketosteroids with $x$ being the total number of carbon atoms. The number after the colon refers to the total number of double bonds. T $x$ and Ta $x$ refer to triterpenoids and triterpenoic acids, respectively, with $x$ referring to their number as assigned in the text and Table 3. Co-eluting compounds are indicated according to their relative contribution, i.e. the most abundant compound is indicated first.

compounds, such as lipids, are less susceptible to leaching than are hydrophilic organic compounds. Alternatively, it could be due to the very small total $\mathrm{C}$ content which would exaggerate any errors in this ratio. The difference between the theoretical yield calculated using the difference in total $\mathrm{C} \%$ between the unextracted and solvent extracted samples (Table 2), and the absolute weight of the total lipid extracts, is caused by losses during the preparation of the extract. The large contribution of free lipids found in the Ah horizon matches the accumulation of aliphatic compounds in $\mathrm{A}$ horizons of acidic soils observed previously (Jambu et al., 1993) and is most likely due to the hydrolysis of wax esters (Jambu et al., 1993).
Molecular composition of total lipid extracts (TLEs) from characteristic horizons

Composition of the TLE from the O horizon. The dominant long-chain $\left(>\mathrm{C}_{27}\right)$ alkanes with a strong odd-over-even predominance (Figure 2a) are usually ascribed to epicuticular waxes and protective layers on vascular plants and commonly observed in lipid extracts from aerial vegetation and (top) soils (Amblès et al., 1989; Jambu et al., 1991). Moreover, the relatively large amounts of $\mathrm{C}_{31}$ and $\mathrm{C}_{33}$ alkanes (Figures $6 \mathrm{c}$ and $7 \mathrm{c}$ ), with smaller contributions of $\mathrm{C}_{27}$ and $\mathrm{C}_{29}$, are characteristic of heather (Calluna) flowers and leaves (Nierop etal., 2001) that grow on top of the profile. A heather-derived input is also reflected in the $n$-alkanol distribution, that 
Table 3 Characteristic mass fragments of steroid and known and unknown triterpenoid compounds (analysed as their trimethylsilyl (TMS) derivatives)

\begin{tabular}{|c|c|c|}
\hline Compound (in order of elution) & Characteristic fragment ions $(m / z)$ & {$[\mathrm{M}]^{+}$} \\
\hline Friedoolean-2-ene $^{\mathrm{a}}(\mathrm{T} 1)^{\mathrm{b}}$ & $69,95,205,218,231,243,257,274,287,395$ & 410 \\
\hline Unidentified triterpenoid (T2) & $73,121,190,204,218,269,359,393,483$ & 498 \\
\hline Friedoolean-14-en-3-one (T3) (taraxerone) ${ }^{\mathrm{a}}$ & $69,81,95,109,189,191,203,205,273,409$ & 424 \\
\hline Friedoolean-14-en-3 $\beta$-ol (T4) (taraxerol) ${ }^{\mathrm{a}}$ & $121,135,189,204,269,284,359,374,393,408,483$ & 498 \\
\hline 24-Ethylcholest-5, 22-dien-3 $\beta$-ol ${ }^{\mathrm{a}, \mathrm{c}, \mathrm{d}}$ (stigmasterol) $\left(\mathrm{S}-\mathrm{C}_{29: 2}\right)$ & $83,129,255,351,379,394,469$ & 484 \\
\hline 24-Ethylcholestan-3 $\beta$-ol $\left(\mathrm{S}-\mathrm{C}_{29}\right)^{\mathrm{a}}$ & $75,95,107,215,257,305,359,383,398,473$ & 488 \\
\hline Ursan-12-en-3 $\beta$-ol ${ }^{\mathrm{c}}$ ( $\alpha$-amyrin) (T5) & $73,95,189,190,203,218,279,393,408,483$ & 498 \\
\hline Lupeol $^{\mathrm{c}, \mathrm{d}}(\mathrm{T} 6)$ & $73,189,190,203,218,369,393,408,483$ & 498 \\
\hline Steroid $^{\mathrm{a}}(\mathrm{S} 1)$ & $69,95,109,134,187,205,259,274,286,393$ & 408 \\
\hline Friedoolean-3-one $^{\mathrm{a}}(\mathrm{T} 8)$ & $69,81,95,109,123,273,302,341,379,411$ & 426 \\
\hline Triterpenoid $^{\mathrm{a}}$ (T9) & $69,81,95,109,121,137,205,218,313,327,341,409,424,481$ & 496 \\
\hline
\end{tabular}

${ }^{\mathrm{a}}$ Van Smeerdijk \& Boon (1987).

${ }^{\mathrm{b}}$ Letters $(\mathrm{T} x, \mathrm{~S} x)$ used in Figure 2 shown in parentheses.

${ }^{c}$ Killops \& Frewin (1994).

${ }^{\mathrm{d}}$ Van Bergen et al. (1997).

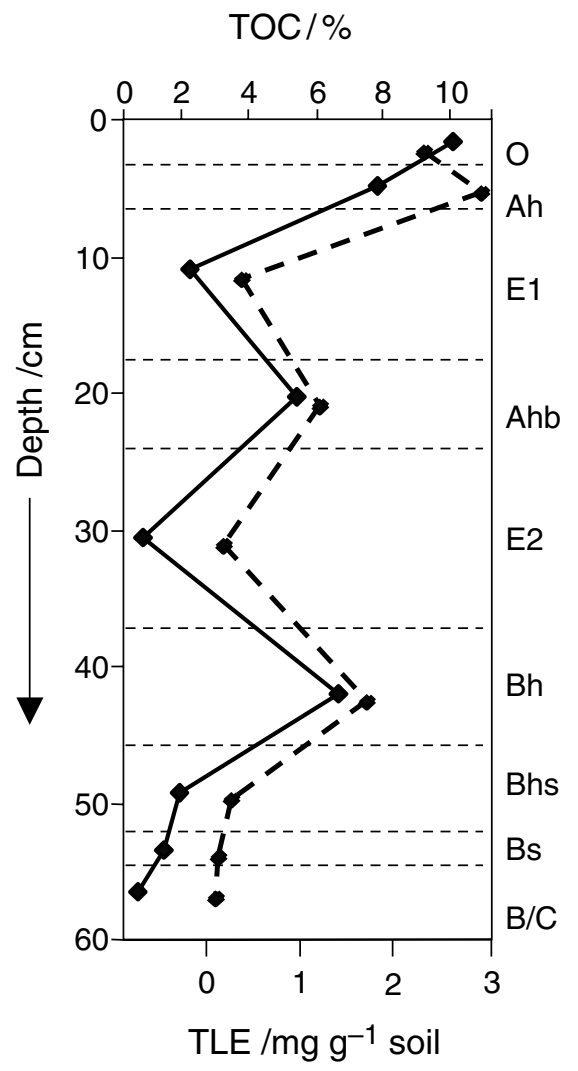

Figure 3 Total organic carbon (TOC) and total lipid extract (TLE) plotted against depth. The TOC is represented by the solid line, and the TLE by the dashed line. Characteristic horizons occur between dashed lines; horizon codes are found at the right. revealed a relatively large abundance of the $C_{22}$ and $C_{24}$ $n$-alkanols characteristic for Calluna stem wood and roots (Nierop, 1998; Nierop et al., 2001) as well as Ericaceae rootlets (van Smeerdijk \& Boon, 1987).

The $n$-alkanoic acids identified can have various natural origins such as plant, fungal or bacterial origins (Amblès et al., 1994b). Straight-chain compounds of fungal origin are similar to those of plant origin, but they range only from $\mathrm{C}_{10}$ to $C_{24}$, often characterized by the presence of unsaturated $C_{16}$ and $\mathrm{C}_{18}$ acids (Weete, 1976; Ruess et al., 2002). Furthermore, long-chain $\left(>\mathrm{C}_{20}\right) n$-alkanoic acids in this topsoil layer may originate from the hydrolysis of wax esters (van Bergen et al., 1998 ) or the oxidation of a variety of other compounds such as $n$-alkanes and $n$-alkanols (Mouçawi et al., 1981; Amblès et al., 1994a,b), processes which are enhanced by a low soil $\mathrm{pH}$ (van Bergen et al., 1998) and the presence of hydrous iron oxides (Mouçawi etal., 1981). The strong even-over-odd dominance and chain-length distribution observed (Figure 2a) imply that odd-chain compounds such as $n$-alkanes are unlikely sources. Based on the same criteria, and the dominance of both $\mathrm{C}_{22}$ and $\mathrm{C}_{24}$ acids, a contribution from the oxidation of $n$-alkanols is more likely.

The $n$-alkanes ranging from $\mathrm{C}_{20}$ to $\mathrm{C}_{27}$, with a carbon preference index close to unity, are more probably of microbial origin (Amblès et al., 1989), although they have also been identified in association with Ericaceae rootlets (van Smeerdijk \& Boon, 1987). A microbial input is also obvious from the iso- and anteiso- $\mathrm{C}_{15}$ fatty acids (Boon et al., 1977), and possibly by the detection of $\mathrm{C}_{18}$ alkenoic acid (Parlanti et al., 1994). 


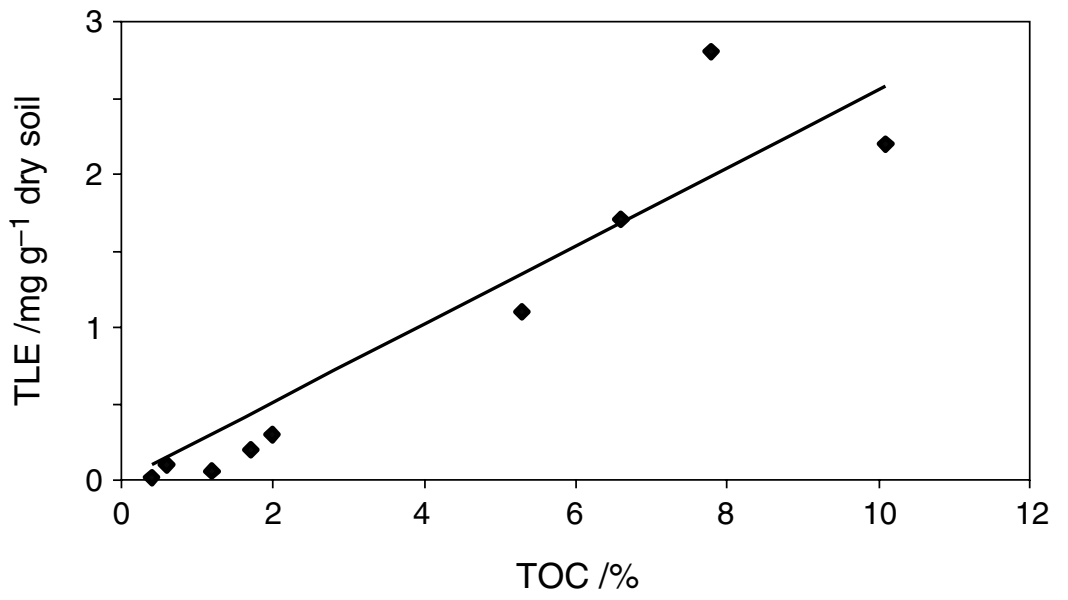

Figure 4 Scatter of total lipid extract (TLE) plotted against total organic carbon (TOC), for which the correlation coefficient, $r$, is 0.94 .
The steroids and triterpenoids identified have frequently been detected in soil and leaf or litter extracts (Killops \& Frewin, 1994; van Bergen et al., 1997; Bull et al., 1998). However, one should note that lupeol, taraxerol, $\alpha$-amyrin and the triterpenoic acid are associated more with aerial vegetation (Killops \& Frewin, 1994). On the other hand, all steroid compounds identified, together with friedoolean-3-one and T9, have been recognized as significant constituents of heather roots (van Smeerdijk \& Boon, 1987; Nierop et al., 2001), although heather leaves and flowers do not contain these compounds in significant amounts (Nierop etal., 2001). In addition to their vascular plant origin, $\mathrm{C}_{29}$ steroids are derived from fungi (Weete, 1976; Grandmougin-Ferjani et al., 1999). Ketosteroids are oxidation products of sterols (Goad, 1991)
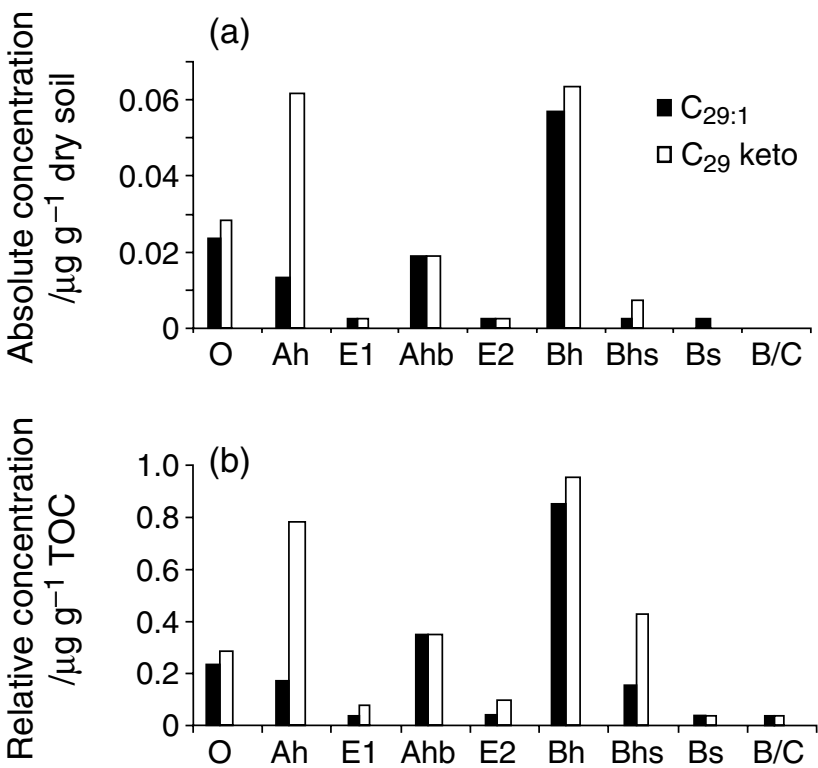

Figure 5 Concentration of $\beta$-sitosterol and $\mathrm{C}_{29}$ ketosteroid by horizon: (a) absolute concentration ( $\mu \mathrm{gg}^{-1}$ dry soil), and (b) relative concentration ( $\left.\mu \mathrm{g} \mathrm{g}^{-1} \mathrm{TOC}\right)$. and have been identified in association with heather rootlets (van Smeerdijk \& Boon, 1987). The $\mathrm{C}_{18}$ isoprenoid methylketone is a degradation product of phytol, which has been found before in total lipid extracts from aerial vegetation (van Bergen etal., 1997; Bull etal., 2000a).

Composition of the TLE from the Ah horizon. Both the relative (Figures $2 \mathrm{~b}$ and $5 \mathrm{~b}$ ) and absolute (Figure 5a) amounts of $\beta$-sitosterol decrease from the litter to the Ah horizon. A decrease in sitosterol, as well as other steroids and terpenoids associated with aerial parts of vegetation (Killops \& Frewin, 1994), was seen when lipids from forest soil litter layers or leaf extracts were compared with those from the underlying A horizon (Jambu etal., 1993; Amblès etal., 1994a,b; van Bergen etal., 1997; Bull etal., 2000a). It is suggested that these compounds are easily mineralized in the soil (van Bergen et al., 1997) or that their decrease in soluble lipid fractions can be caused by their condensation into more stable, insoluble moieties (Gobé et al., 2000). In addition, they may be chemically altered to form modified steroids and triterpenoids (van Bergen et al., 1997).

The significant increase in concentration of the $\mathrm{C}_{29}$ ketosteroid (Figure 5) and taraxerone from the $\mathrm{O}$ to the $\mathrm{Ah}$ horizon probably results from oxidation (van Bergen etal., 1997). In addition, taraxerone (T3), friedoolean-3-one (T8) and T9 triterpenoids have also been found in heather rootlets (van Smeerdijk \& Boon, 1987; Nierop et al., 2001), reflecting a direct input. In general, more unsaturated compounds are more susceptible to (microbial) degradation. The total decrease of stigmasterol $\left(\mathrm{C}_{29: 2}\right)$ compared with that of $\beta$-sitosterol $\left(\mathrm{C}_{29: 1}\right)$ is therefore related to the degree of unsaturation. In addition, a source of $\beta$-sitosterol has been found in ester-linked lipids obtained from soil samples taken from a depth of $15-50 \mathrm{~cm}$ (Naafs \& van Bergen, 2002).

Another group of lipids that decreases rapidly from the $\mathrm{O}$ to the Ah horizon is the $n$-alkanes (Figures $6 \mathrm{c}$ and $7 \mathrm{c}$ ), as observed in acid soils (Marseille et al., 1999). This decrease in $n$-alkane concentration is accompanied by an increase in the 
(a)
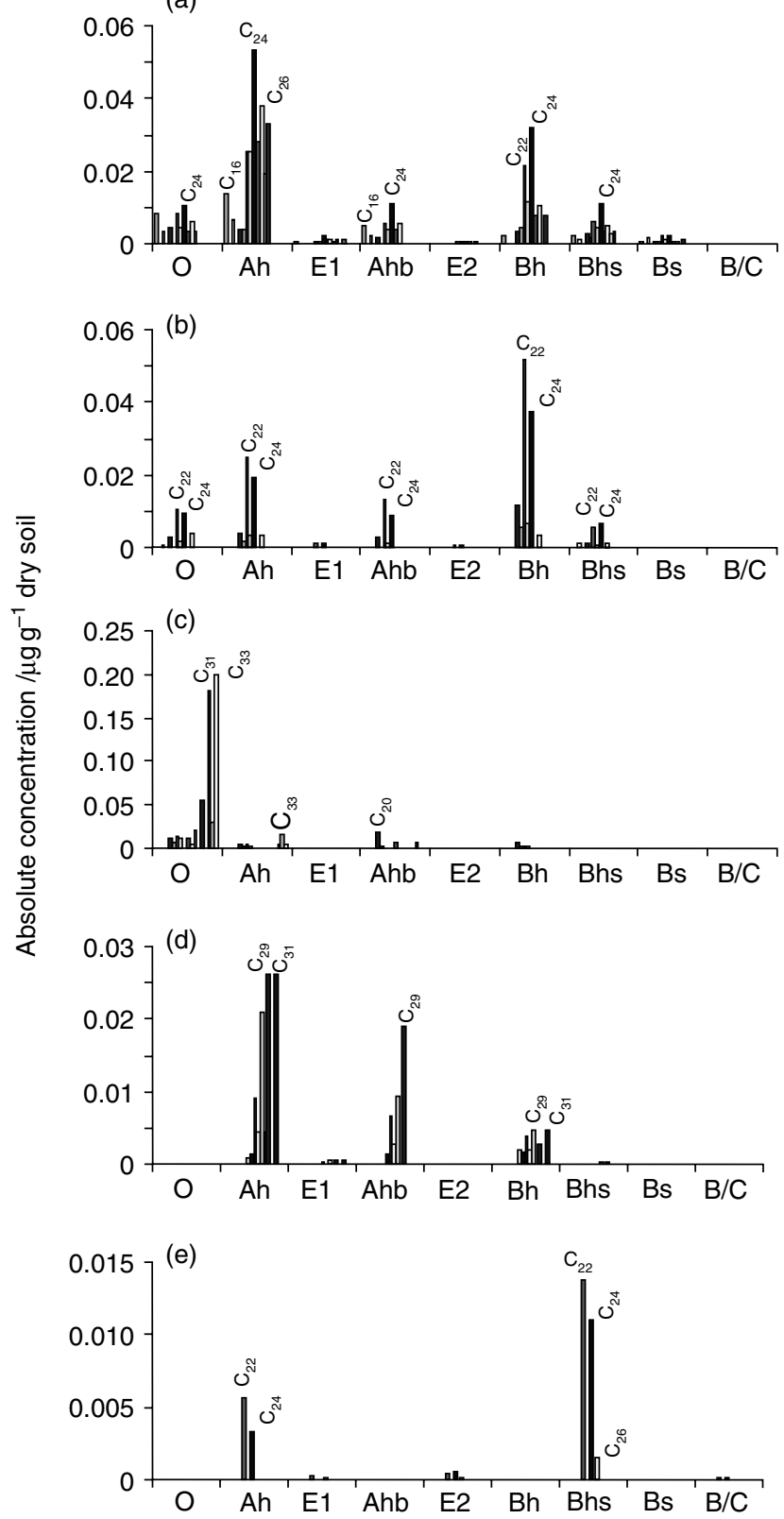

Figure 6 Absolute concentration ( $\mu \mathrm{gg}^{-1}$ dry soil) of $\mathrm{C}_{16}-\mathrm{C}_{33}$ lipid compounds by horizon: (a) $n$-alkanoic acids, (b) $n$-alkanols, (c) $n$ alkanes, (d) ketones, and (e) $\omega$-hydroxy acids.

concentration of methylketones (Figures $2 b, 6 d$ and $7 d$ ), which are not known as primary plant products. Considering that $n$-alkanes are a likely substrate for in situ microbial $\beta$-oxidation based on similarities found in the distribution of ketones and $n$-alkanes (Amblès et al., 1993), and that such similarities are found in the podzol profile (Figure 2a), we assume that methylketones in the Ah horizon are derived from such oxidation. The relatively small contribution of methylketones to the total amount of lipids in the litter layer (Figure 6d) is expected because methylketones are usually detected in such
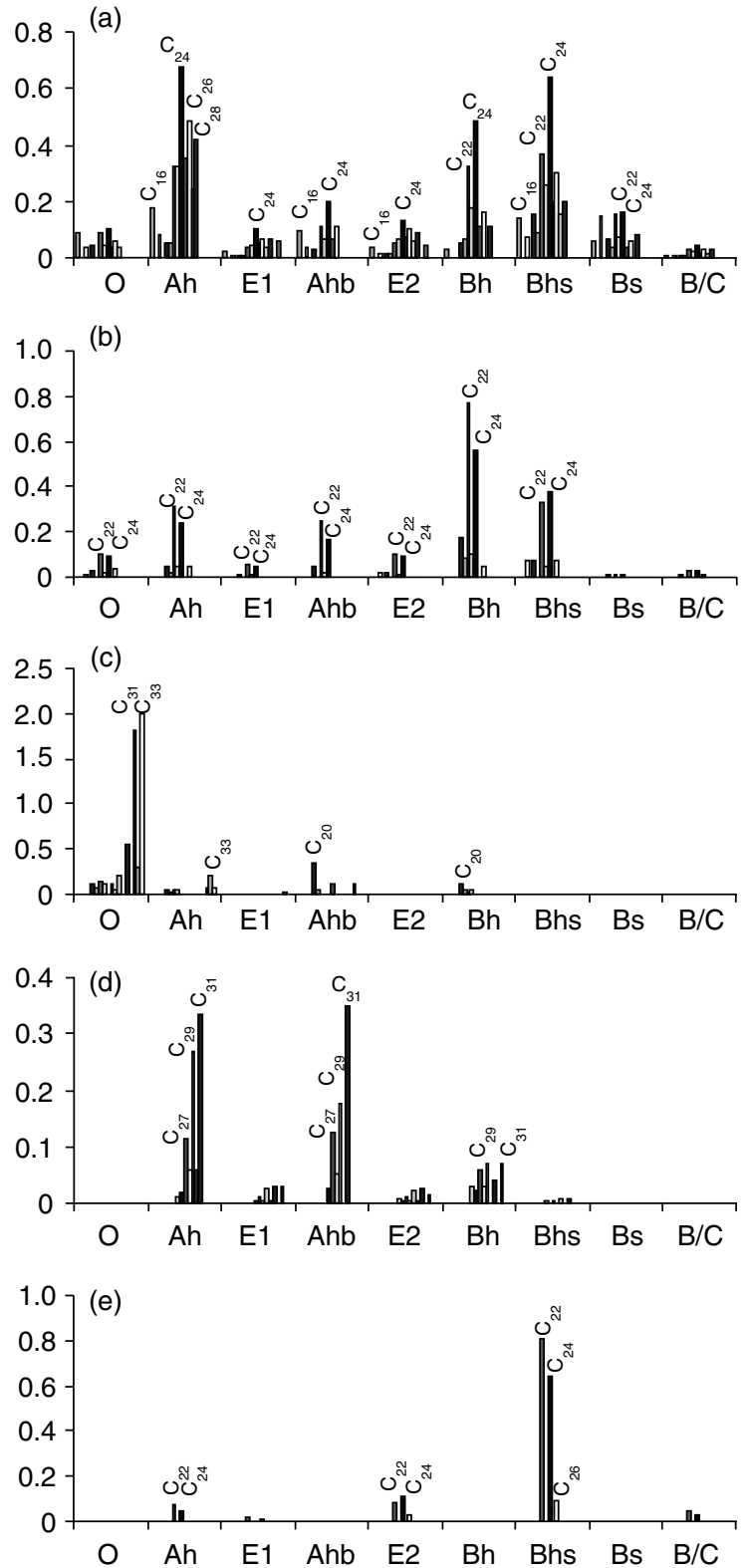

Figure 7 Relative concentration ( $\mu \mathrm{g} \mathrm{g}^{-1}$ TOC) of $\mathrm{C}_{16}-\mathrm{C}_{33}$ lipid compounds by horizon: (a) $n$-alkanoic acids, (b) $n$-alkanols, (c) $n$-alkanes, (d) ketones, and (e) $\omega$-hydroxy acids.

layers only in trace amounts (Amblès et al., 1993). Furthermore, because of their biodegradation, the amount of methylketones determined in soil is much less than the amounts produced from $n$-alkanes (Amblès et al., 1993).

The increase in absolute (Figure 6a) and relative (Figure 7a) concentrations of long-chain $\left(>\mathrm{C}_{20}\right)$ n-alkanoic acids (cf. Amblès et al., 1994b), together with the increase in the total amount of lipids (Figure 3), indicates that these compounds are produced in the Ah horizon. Hydrolysis of wax esters (van Bergen et al., 1998) and an input from roots (Bull et al., $2000 \mathrm{~b}$ ) are the most likely processes involved. The presence of 
hexadecanoic acid and $\mathrm{C}_{18} n$-alkenoic acid could be related to an input from mosses (Nierop et al., 2001), but the acid has also been observed in root- and rhizosphere-derived total lipid extracts (Bull et al., 2000a,b). Moreover, short-chain $\left(<\mathrm{C}_{20}\right)$ acids, including $\mathrm{C}_{14}, \mathrm{C}_{16}, \mathrm{C}_{18: 1}$ and $\mathrm{C}_{18}$ fatty acids, were found to be the dominant acids leached from the litter and $\mathrm{Ah}$ horizon during an experimental study of podzol soil lipids (Amblès et al., 1998).

The absolute (Figure $6 \mathrm{~b}$ ) and relative (Figure $7 \mathrm{~b}$ ) increase in the concentration of $n$-alkanols is most likely to be the result of an input both from heather roots, considering their relatively large abundance in heather root pyrolysates (van Smeerdijk \& Boon, 1987; Nierop, 1998; Nierop et al., 2001), and from the hydrolysis of wax esters (Jambu et al., 1993). The latter process is enhanced by the low soil $\mathrm{pH}$ (Wolfe et al., 1989). The detection of $\mathrm{C}_{22}$ and $\mathrm{C}_{24} \omega$-hydroxy acids (Figures $6 \mathrm{e}$ and $7 \mathrm{e}$ ) in this horizon reveals an input derived possibly both from aerial vegetation as well as from roots (Bull et al., 2000b).

Composition of the TLE from the E1 horizon. As mentioned, the composition of the total lipid extract from the E1 horizon (Figure 2c) resembles to a great extent that from the overlying Ah horizon (Figure 2b). If we take into account the large $\mathrm{C}$ content $(2 \%)$ for a leached horizon (Figure 3 ), this strongly suggests to us that the process of formation of this E1 horizon is not yet complete, although both absolute and relative amounts of lipids are very small (Figures 6 and 7). Normalized to the total $\mathrm{C} \%$ there is, apart from the decrease in $n$-alkanoic acids and $n$-alkanols, a strong decrease in the concentration of ketones (Figure 7d) caused by their relatively rapid biodegradation as intermediates in the $n$-alkane degradation pathway (Amblès et al., 1993).

Composition of the TLE from the Ahb horizon. The Ahb extract again shows a signal dominated by steroids and triterpenoids (Figure 2d), with abundant contributions from $\beta$-sitosterol (see also Figure 5), $\mathrm{C}_{29}$ ketosteroid, and friedoolean-2-ene (T1), $\mathrm{T} 2$, friedoolean-3-one (T8) and T9 triterpenoids. All these compounds have been identified in heather rootlets (van Smeerdijk \& Boon, 1987). Relative to the total C\%, $\beta$-sitosterol (Figure 5b), $n$-alkanols (Figure 7b) and ketones (Figure 7d) show a significant increase. These compounds are enriched in the buried A horizon either as remnants of the buried vegetation, or as the result of an input by roots (Nierop etal., 2001). A contribution from above-ground litter lipids through transport to Ah horizons in sandy soils, on the other hand, has been found to be negligible. Possible evidence for a contribution from previous vegetation could be the increase in both absolute (Figure 6d) and relative (Figure 7d) methylketone concentrations most probably derived from the oxidation of n-alkanes (Amblès et al., 1993; van Bergen et al., 1997).

Composition of the TLE from the E2 horizon. $\mathrm{C}_{22}$ and $\mathrm{C}_{24}$ $\omega$-hydroxy acids, in combination with long-chain $\left(>\mathrm{C}_{20}\right)$ acids and $\mathrm{C}_{22}$ and $\mathrm{C}_{24} n$-alkanols, are the lipids that remain in the E2 horizon. In addition to these root-derived compounds (Nierop, 1998; Naafs etal., 2004), $\mathrm{C}_{8}$ and $\mathrm{C}_{9} \omega$-hydroxy acids were detected, probably as a result of the oxidation (Regert etal., 1998) of unsaturated suberin building blocks (Nierop etal., 2003). Note that the distributions of both $n$-alkanoic acids and $\omega$-hydroxy acids resemble those observed in samples of rhizosphere and mineral horizons (Bull et al., 2000a,b).

Methylketones also remain in this horizon as oxidation products of alkanes (Amblès etal., 1993). Because of this intensive leaching or degradation, absolute amounts of all compounds identified in this horizon are very small (Figure 6). Normalized to the total $\mathrm{C} \%$, however, it is shown that the decrease in the contribution of lipids to the total amount of $\mathrm{C}$ is caused mainly by a decrease in steroids (Figure 5b), triterpenoids and ketones (Figure 7d). Because of the labile nature of these compounds (van Bergen et al., 1997) and their hydrophobicity, (microbial) degradation of these compounds seems the most likely explanation for this decrease. The contributions of $n$-alkanoic acids (Figure 7a), $n$-alkanols (Figure 7b) and $\omega$-hydroxy acids (Figure 7e), by contrast, remain similar, or even increase. These compounds therefore reflect a rootderived input that is hard to degrade or leach. No evidence of accumulation of lipids derived from the soil surface, such as long-chain $\left(>\mathrm{C}_{20}\right) n$-alkanes, has been observed in the E2 horizon. Thus, the E2 signal could be considered to be derived from an input by roots.

Composition of the TLE from the Bh horizon. Just as observed for the $\mathrm{O}$ and $\mathrm{Ahb}$ horizons, the organic matter rich $\mathrm{Bh}$ horizon is characterized by $\beta$-sitosterol and $\mathrm{C}_{29}$ ketosteroid, a series of triterpenoids, and $\mathrm{C}_{22}$ and $\mathrm{C}_{24} n$-alkanols (Figure 2f). Comparison with the large total C content (Figure 3), and both absolute and relative amounts of lipid compounds identified, clearly indicates that organic matter, including lipids, accumulates in this horizon. Podzol B horizons might contain more root-derived than illuviated organic matter (van Breemen \& Buurman, 1998).

The contribution of litter-derived organic matter to the subsoil in sandy soils was found to be negligible (Nierop et al., 2001). Moreover, roots were found to develop preferentially in podzol Bh horizons (De Coninck, 1980). Thus, the significant increase in the contribution of steroids (Figure 5), triterpenoids and $\mathrm{C}_{22}$ and $\mathrm{C}_{24} n$-alkanols (Figures $6 \mathrm{~b}$ and $7 \mathrm{~b}$ ), all known to be derived from heather roots (van Smeerdijk \& Boon, 1987; Nierop \& Buurman, 1999; Nierop et al., 2001), can be interpreted as resulting from the accumulation of rootderived lipids produced in situ. In addition to this root-derived signal, a bacterial contribution is again reflected in the presence of short-chain alkanes and methylketones. Note that, like the observations by Nierop \& Buurman (1999) with respect to the insoluble organic matter fraction, we found no evidence for a contribution from lipid compounds transported from the top of the profile. 
Composition of the TLE from the transition from the Bh to the Bs horizon. In the sample from the transition layer between the Bh and Bs horizons (Bhs; Figure 2g), the total lipid signal again changes dramatically into a signal dominated by $\omega$-hydroxy acids (Figures 6e and 7e) and $n$-alkanoic acids, as observed for the E2 horizon (Figure 2e). The sharp decrease in total $\mathrm{C}$ content (Figure 3) indicates that no accumulation of organic matter took place in this horizon, again strongly suggesting that the signal observed is characteristic for a degraded root-derived input. The microbial signal in this horizon comprises short-chain alkanes and methylketones. It has been suggested that complexed organic matter is degraded in this horizon to yield $\mathrm{Al}$ and $\mathrm{Fe}$ which then precipitate in the underlying Bs horizon (Lundström etal., 1995). We suggest that this degradation may also affect the biopolyester suberin, resulting in the release of relatively large amounts of longchain $\left(>\mathrm{C}_{20}\right) \omega$-hydroxy acids (Figures 5 e and $6 \mathrm{e}$ ) characteristic of an input by roots to the lipid signal in soils (Bull et al., 2000b; Naafs et al., 2004).

Composition of the TLE from the Bs and B/C horizons. Both the total organic carbon contents (Figure 3) and absolute amounts of lipids (Figures 3 and 6) are very small in the Bs horizon (Figure 2h). The signal observed most probably reflects the very small remnant of lipids or a minor contribution from lipids that penetrate into this hard layer from the overlying Bhs horizon (Figure 2g). Again, most root-derived steroids and triterpenoids have been degraded.

The total lipid signal from the $\mathrm{B} / \mathrm{C}$ horizon (Figure $2 \mathrm{i}$ ) again resembles that of the other horizons with a small total $\mathrm{C}$ content, i.e. the E2, Bhs and Bs horizons (Figure 3). The lipid signal consists of compounds derived from degraded remnants of old roots that were present in this horizon before it was cut off from the rest of the profile by the formation of the hard, cemented Bs horizon (De Coninck, 1980).

Implications of lipid data for the podzolization process. The lipids in the Bh horizon are derived mainly from a fresh input by roots that accumulate in this horizon. The limited penetration of lipids derived from the surface vegetation into the profile indicates that the influence of vertical transport of lipids is negligible compared with (bacterial) degradation. The detection of lipid degradation products such as ketones, and bacterial markers such as short-chain alkanes and fatty acids throughout the profile, further indicates that (bacterial) degradation of lipids is an important process in this podzol profile. Because both steroids and triterpenoids have been shown to degrade rapidly within soils (van Bergen et al., 1997), this is a likely explanation for their small concentration in podzol E horizons. After degradation of most of these steroids and triterpenoids, a signal derived from bacteria and root-derived long-chain fatty acids and $\omega$-hydroxy acids remains in the $\mathrm{E}$ horizon. These latter compounds reflect in situ lipid input produced by the degradation of remnants of root suberins and remain after degradation of the rest of the root-derived lipids.

\section{Conclusions}

The composition of total lipid extracts from nine characteristic horizons in a podzol from the Veluwe area (The Netherlands) has been analysed by gas chromatography (GC) and gas chromatography-mass spectrometry (GC/MS). In addition, soil $\mathrm{pH}\left(\mathrm{H}_{2} \mathrm{O}\right)$ and ammonium oxalate- and sodium pyrophosphate-extractable aluminium and iron were determined. From these analyses we conclude the following.

1 Lipids accumulate in horizons with large organic matter contents, but there is no increase relative to other soil organic matter.

2 An $n$-alkane, steroid and triterpenoid signal related to the aerial parts, i.e. leaves and flowers, of Calluna is observed only in the O horizon. This signal is quickly lost in the underlying Ah horizon as a result of (bacterial) oxidation.

3 All total lipid extracts, except that from the $\mathrm{O}$ horizon, are dominated by root-derived lipids.

4 In subsoil horizons with large organic matter contents, i.e. the $\mathrm{Ahb}$ and $\mathrm{Bh}$ horizons, root-derived friedooleanan and steroid compounds dominate the total lipid signal.

$5 \mathrm{C}_{22}$ and $\mathrm{C}_{24} \omega$-hydroxy acids, long-chain $\left(>\mathrm{C}_{20}\right) n$-alkanoic acids with a strong even-over-odd dominance and $\mathrm{C}_{22}$ and $\mathrm{C}_{24}$ $n$-alkanols, characteristic of an input from roots, dominate the horizons with small contents of organic matter, i.e. the E2, Bhs, Bs and B/C horizons. Steroid- and root-derived triterpenoids with a friedoolean structure, once present in these horizons, have been degraded.

6 Based on total C content and molecular lipid composition, the formation of an E1 horizon has started, but is not yet complete.

7 In the Ahb horizon, a contribution from buried vegetation to the total lipid signal is still present, although degradation and an input by roots have significantly altered the original signal.

8 Overall, lipid data indicate that degradation of lipids (mainly oxidation) is an important process that should be taken into account, in addition to leaching, when describing the so-called 'podzolization process' in soils.

\section{Acknowledgements}

This study was supported by the Institute for Palaeoenvironment and Palaeoclimate Utrecht (IPPU). We thank M.van Alphen and T. Zalm for their help with the GC and GC/MS analyses, Dr J. Kool for supplying additional data and graphs, and two reviewers for their comments and suggestions. Both the associate editor, Dr L. Petersen, and the Editor, Dr P. Loveland, are sincerely thanked for their help with the final editing and 
formatting, as well as useful comments and suggestions on the contents of the paper.

\section{References}

Amblès, A., Jambu, P., Jacquesy, J.-C., Parlanti, E. \& Secouet, B. 1993. Changes in the ketone portion of lipidic components during the decomposition of plant debris in a hydromorphic forest-podzol. Soil Science, 156, 49-56.

Amblès, A., Parlanti, E., Jambu, P., Mayoungou, P. \& Jacquesy, J.-C. 1994a. n-Alkane oxidation in soil. Formation of internal monoalkenes. Geoderma, 64, 111-124.

Amblès, A., Jambu, P., Parlanti, E., Joffre, J. \& Riffe, C. 1994b. Incorporation of natural monoacids from plant residues into a hydromorphic forest podzol. European Journal of Soil Science, 45, 175-182.

Amblès, A., Magnoux, P., Jacquesy, R. \& Fustec, E. 1989. Effects of addition of bentonite on the hydrocarbon fraction of a podzol soil (A Horizon). Journal of Soil Science, 40, 685-694.

Amblès, A., Colina-Tejada, A., Jambu, P., Lemee, L. \& Parlanti, E. 1998. Experimental leaching of podzol soil lipids. Nature and biological origin of water soluble components. Agrochimica, 42, $158-171$.

Boon, J.J., de Leeuw, J.W., Hoeck, J. \& Vosjian, J. 1977. Significance and taxonomic value of iso and anteiso monoenoic fatty acids and branched b-hydroxyacids in Desulfovibrio desulfuricans. Journal of Bacteriology, 129, 1183-1191.

Bull, I.D., van Bergen, P.F., Poulton, P.R. \& Evershed, R.P. 1998. Organic geochemical studies of soils from the Rothamsted Classical Experiments. II. Soils from the Hoosfield Spring Barley Experiment treated with different quantities of manure. Organic Geochemistry, 28, 11-26.

Bull, I.D., van Bergen, P.F., Nott, C.J., Poulton, P.R. \& Evershed, R.P. 2000a. Organic geochemical studies of soils from the Rothamsted Classical Experiments. V. The fate of lipids in different long-term experiments. Organic Geochemistry, 31, 389-408.

Bull, I.D., Nott, C.J., van Bergen, P.F., Poulton, P.R. \& Evershed, R.P. 2000b. Organic geochemical studies of soils from the Rothamsted Classical Experiments. VI. The occurrence and source of organic acids in an experimental grassland soil. Soil Biology and Biochemistry, 32, 1367-1376.

De Coninck, F. 1980. Major mechanisms in formation of spodic horizons. Geoderma, 24, 101-128.

FAO 1998. World Reference Base for Soil Resources. World Soil Resources Report 84, Food and Agriculture Organisation of the United Nations, Rome.

Goad, L.J. 1991. Phytosterols. Methods in Plant Biochemistry, 7, 369-434.

Gobé, V., Lemée, L. \& Amblès, A. 2000. Structure elucidation of soil macromolecular lipids by preparative pyrolysis and thermochemolysis. Organic Geochemistry, 31, 409-419.

Grandmougin-Ferjani, A., Dalphé, Y., Hartmann, M.-A., Laruelle, F. \& Sancholle, M. 1999. Sterol distribution in arbuscular mycorrhizal fungi. Phytochemistry, 50, 1027-1031.

Holloway, P.J. 1982. The chemical constitution of plant cutins. In: The Plant Cuticle (eds D.F. Cutler, K.L. Alvin \& C.E. Price), pp. 45-85. Linnean Society Symposium Series No 10, Academic Press, London.
Jambu, P., Mouçawi, J., Fustec, E., Amblès, A. \& Jacquesy, R. 1985. Interrelation entre $\mathrm{pH}$ et la nature des composes lipiques du sol: étude comparée d'une rendzine et d'un sol lessivé glossique. Agrochimica, 29, 186-198.

Jambu, P., Amblès, A., Dinel, H. \& Secouet, B. 1991. Incorporation of natural hydrocarbons from plant residues into a hydromorphic humic podzol following afforestation and fertilization. Journal of Soil Science, 42, 629-636.

Jambu, P., Amblès, A., Jacquesy, J.-C., Secouet, B. \& Parlanti, E. 1993. Incorporation of natural alcohols from plant residues into a hydromorphic forest-podzol. Journal of Soil Science, 44, 135-146.

Killops, S.D. \& Frewin, N.L. 1994. Triterpenoid diagenesis and cuticular preservation. Organic Geochemistry, 21, 1193-1209.

Lundström, U.S., van Breemen, N. \& Jongmans, A.G. 1995. Evidence for microbial decomposition of organic acids during podzolization. European Journal of Soil Science, 46, 489-496.

Marseille, F., Disnar, J.R., Guillet, B. \& Noack, Y. 1999. n-Alkanes and free fatty acids in humus and A1 horizons of soils under beech, spruce and grass in the Massif-Central (Mont-Lozère), France. European Journal of Soil Science, 50, 433-441.

Mouçawi, J., Fustec, E., Jambu, P., Amblès, A. \& Jacquesly, R. 1981. Biooxidation of added and natural hydrocarbons in soils: effects of iron. Soil Biology and Biochemistry, 13, 335-342.

Naafs, D.F.W. \& van Bergen, P.F. 2002. A qualitative study on the chemical composition of ester-bound moieties in an acidic andosolic forest soil. Organic Geochemistry, 33, 189-199.

Naafs, D.F.W., van Bergen, P.F., Boogert, S.J. \& de Leeuw, J.W. 2004. Solvent-extractable lipids in an acid andic forest soil: variations with depth and season. Soil Biology and Biochemistry, 36, 297-308.

Nierop, K.G.J. 1998. The origin of aliphatic compounds in a forest soil. Organic Geochemistry, 29, 1009-1016.

Nierop, K.G.J. \& Buurman, P. 1999. Insoluble organic matter fractions in incipient podzol B horizons: preservation of aliphatic biopolymers from roots. Humic Substances in the Environment, 1, 29-37.

Nierop, K.G.J., van Lagen, B. \& Buurman, P. 2001. Composition of plant tissues and soil organic matter in the first stages of a vegetation succession. Geoderma, 100, 1-24.

Nierop, K.G.J., Naafs, D.F.W. \& Verstraten, J.M. 2003. Occurrence and distribution of ester-bound lipids in Dutch coastal dune soils along a pH gradient. Organic Geochemistry, 34, 719-729.

Parlanti, E., Hita, C., Jambu, P., Dinel, H. \& Amblès, A. 1994. The internal double-bond insertion: a side reaction of aliphatic hydrocarbons degradation in soil. Soil Biology and Biochemistry, 26, 1375-1378.

Regert, M., Bland, H.A., Dudd, S.N., van Bergen, P.F. \& Evershed, R.P. 1998. Free and bound fatty acid oxidation products in archaeological ceramic vessels. Proceedings of the Royal Society of London B, 265, 2027-2032.

Ruess, L., Häggblom, M.M., García Zapata, E.J. \& Dighton, J. 2002. Fatty acids of fungi and nematodes - possible biomarkers in the soil food chain? Soil Biology and Biochemistry, 34, 745-756.

Schmidt, M.W.I., Knicker, H. \& Kögel-Knabner, I. 2000. Organic matter accumulating in Aeh and Bh horizons of a podzol - chemical characterization in primary organo-mineral associations. Organic Geochemistry, 31, 727-734.

Stevenson, F.J. 1982. Soil lipids. In: Humus Chemistry, pp. 172-194. John Wiley \& Sons, New York. 
Van Bergen, P.F., Bull, I.D., Poulton, P. \& Evershed, R.P. 1997. Organic geochemical studies of soils from the Rothamsted Classical Experiments. I. Total lipid extracts, solvent insoluble residues and humic acids from Broadbalk Wilderness. Organic Geochemistry, 26, 117-135.

Van Bergen, P.F., Nott, C.J., Bull, I.D., Poulton, P.R. \& Evershed, R.P. 1998. Organic geochemical studies of soils from the Rothamsted Classical Experiments. IV. Preliminary results from a study of the effect of soil pH on organic matter decay. Organic Geochemistry, 29, 1779-1795.

Van Breemen, N. \& Buurman, P. 1998. Soil Formation. Kluwer Academic Publishers, Dordrecht.

Van Smeerdijk, D.G. \& Boon, J.J. 1987. Characterisation of subfossil Sphagnum leaves, rootlets of Ericaceae and their peat by pyrolysis- high resolution gas chromatography mass spectrometry. Journal of Analytical and Applied Pyrolysis, 11, 377-402.

Weete, J.D. 1976. Algal and fungal waxes. In: Chemistry and Biochemistry of Natural Waxes (ed. P.E. Kolattukudy), pp. 349-418. Elsevier, Amsterdam.

Wesselink, L.G., van Breemen, N., Mulder, J. \& Janssen, P.H. 1996. A simple model of soil organic matter complexation to predict the solubility of aluminium in acid forest soils. European Journal of Soil Science, 47, 373-384.

Wolfe, N.L., Metwally, M.E.S. \& Moftah, A.E. 1989. Hydrolytic transformations of organic chemicals in the environment. In: Reactions and Movement of Organic Chemicals in Soils (eds B.L. Sawhney \& K. Brown), pp. 229-242. Special Publication No 2, Soil Science Society of America, Madison, WI. 
